\title{
Strategies to include sweet potato meal associated with the use of exogenous enzymes, in broiler chicken feed
}

\author{
Estratégias de inclusão da farinha de batata doce associada ao uso de enzimas \\ exógenas em rações de frangos de corte
}

\author{
BAHULE, Celina Eugenio $^{1 *}$; BRITO, Jerônimo Ávito Gonçalves de ${ }^{1}$; BALBINO, Eric \\ Marcio $^{2}$; MACHADO, Adriana Conceição ${ }^{3}$; BATISTA, Saulo Silva ${ }^{3}$; OLIVEIRA, \\ Lennon Santos ${ }^{1}$; SILVA, Tamiris Natalice Santos ${ }^{3}$; PEREIRA, Jamile ${ }^{3}$
}

\footnotetext{
${ }^{1}$ Universidade Federal do Recôncavo da Bahia, Programa de Pós-graduação em Ciência Animal, Cruz das Almas, Bahia, Brasil.

${ }^{2}$ Universidade Federal do Recôncavo da Bahia, Centro de Ciências Agrárias, Ambientais e Biológicas, Cruz das Almas, Bahia, Brasil. Bolsista PNPD-CAPES.

${ }^{3}$ Universidade Federal do Recôncavo da Bahia, Centro de Ciências Agrárias, Ambientais e Biológicas, Cruz das Almas, Bahia, Brasil.

*Endereço para correspondência: celinabahule@gmail.com
}

\section{SUMMARY}

This work evaluated the effect of including sweet potato meal (SPM), as an alternative to corn in broiler chicken diets, on performance, carcass yield, intestinal morphometry, organ biometry, meat quality and drumstick pigmentation. The study used 936 male Cobb-500 chicks. The experiment had a completely randomized, $3 \times 2$ factorial design, with three diet types. These included corn as the energetic ingredient in the standard diet (corn-soybean meal, CSM), and an increasing (ISP) and decreasing (DSP) inclusion of sweet potato meal as a corn substitute, in association with exogenous enzymes, for a total of six treatments with six repetitions and 26 birds per plot. During the period of 1 to 21 days, there was an interaction $(\mathrm{P}<0.05)$ for the weight gain $(\mathrm{WG})$ variable; the CSM diets promoted greater $\mathrm{WG}$ in relation to the ISP and DSP groups, when supplemented with exogenous enzymes. There was an increase $(\mathrm{P}<0.05)$ in surface absorption of the jejunum villi and relative weight of the pancreas, and worse feed conversion (FC), for the ISP and DSP diets. With exception of the pancreas, for the entire period of 1 to 39 days the performance, yield of the carcass and cuts, meat quality, relative weight of the liver, and feet pigmentation variables were not affected $(\mathrm{P}>0.05)$ by the factors evaluated. Sweet potato meal, independent of the inclusion program (ISP/DSP) and enzyme supplementation, could partially substitute corn in broiler chicken feed, guaranteeing good performance, carcass yield and meat quality.

Keywords: alternative feed, meat quality, performance

\section{RESUMO}

Avaliou-se o efeito da inclusão de farinha de batata doce (FBD), como alternativa ao milho em dietas de frangos de corte sobre o desempenho, rendimento da carcaça, morfometria intestinal, biometria de órgãos, qualidade de carne e pigmentação de canela. Foram utilizados 936 pintos de um dia, machos, da linhagem Cobb-500. Adotou-se um DIC em esquema fatorial $3 \times 2$, sendo três tipos de dietas, sendo o milho o ingrediente energético na dieta padrão (MFS), inclusão crescente (BDC) e decrescente (BDD) de farinha de batata doce como substituto parcial ao milho, associadas ou não ao uso de enzimas exógenas, totalizando seis tratamentos com seis repetições e 26 aves por parcela. No período de 1 a 21 dias, houve interação $(\mathrm{P}<0,05)$ para as variáveis de ganho de peso (GP) onde as dietas de MFS promoveram maior GP em relação aos grupos BDC e BDD quando suplementado com enzimas exógenas. Houve aumento $(\mathrm{P}<0,05)$ da superfície 
de absorção das vilosidades do jejuno, do peso relativo do pâncreas e piora na conversão alimentar (CA) promovido pelas dietas com BDC e BDD. No período integral de 1 a 39 dias (com exceção para o pâncreas) as variáveis desempenho, rendimento da carcaça e dos cortes, qualidade de carne, peso relativo do fígado e pigmentação das canelas não foram afetados $(\mathrm{P}>0,05)$ pelos fatores avaliados. A farinha de batata doce independente do programa de inclusão (BDC/BDD) e da suplementação de enzimas pode ser usada em rações de frangos de corte, garantindo bom desempenho, rendimento de carcaça e qualidade de carne.

Palavras-chave: alimento alternativo, qualidade de carne, desempenho

\section{INTRODUCTION}

The Brazilian aviculture industry has a robust raw materials market for feed, which gives the country a competitive advantage. Corn, the main ingredient in feed, is produced on a massive scale and exported. However, not all regions of the world, as well as Brazilian states, can do this due to unfavorable climatic and soil conditions, use of corn for human consumption, and the financing needed to produce and/or import this resource (OLIVEIRA et al., 2014; PANDI et al., 2016).

There are alternative ingredients for broiler chicken feed that have the same potential and are inexpensive and easy to acquire, such as sweet potato. Sweet potato is a rustic plant that can be cultivated in poor and disturbed soils in various climates and has a high yield per hectare in some states, making it a good alternative to corn (OLIVEIRA et al., 2015; LAURIE et al., 2015).

For small poultry producers, sweet potato is a good alternative to reduce production costs of broiler chickens (conventional or free-range), and breeders can also locally cultivate this tuberous root.
Sweet potato meal (SPM) contains the same amount or more starch than corn (ROSTAGNO et al., 2011; LAURIE et al., 2015). Starch with more amylopectin than amylose (WARAMBOI et al., 2011; WALUYO et al., 2015) can be associated with nonstarch polysaccharides (NSPs), which can have an antinutritional effect. Thus, adding exogenous enzymes to chicken diets it commonly practiced because it can minimize problems (HORVATOVIC et al., 2015).

Exogenous enzymes enhance nutrient utilization and, thus, optimize the use of metabolizable energy in diets (RAVINDRAN, 2013). Tests made with SPM have reported controversial results, some negative (SET'LE et al. 2012; PARENTE et al. 2014) and some positive, in relation to unchanged performance, carcass yield and meat quality attributes (BECKFORD \& BARTLETT, 2015).

The objective of this work was to evaluate the effect of using SPM as an alternative to corn in broiler chicken feed. The study used different inclusion programs (increasing and decreasing amounts) according to the stages of the feeding program for broiler chickens, in association with an exogenous enzyme supplement, to assess performance, carcass yield, meat quality, internal organ biometry and morphometry of the intestinal segments.

\section{MATERIAL AND METHODS}

All the procedures performed in this study followed the standards and norms of the resolutions of the National Council of Control of Animal Experimentation (Conselho Nacional de Controle de Experimentação Animal - CONCEA).

The experiment was conducted in the Aviculture Sector of the Center for 
Agrarian, Environmental and Biological Sciences at the Federal University of Recôncavo da Bahia (Setor de Avicultura do Centro, Ciências Agrárias, Ambientais e Biológicas, Universidade Federal do Recôncavo da Bahia - CCAAB/UFRB) in the municipality of Cruz das Almas.

The study used 936 male Cobb-500 chicks from a hatchery registered in MAPA, which were housed in an experimental barn in 36 boxes $(1.72 \times$ $1.82 \mathrm{~m}$ ) with a floor covered in $10 \mathrm{~cm}$ of shavings (reused), a tubular feeder, and a bell drinker. The boxes were heated with bell-shaped lamps with 150-watt infrared bulbs.

The light program adopted was $23 \mathrm{~L}: 1 \mathrm{D}$, 14L:10D, 16L:8D in the first, second and third week, respectively, and 18L:6D was used from the beginning of the fourth week to end of the experiment.

The experiment had a completely randomized, 3x2 factorial design, with three diet types: 1- corn as the energetic ingredient (corn-soybean meal, CSM); 2 - increasing inclusion of sweet potato meal (ISP) as a partial corn substitute; and 3- decreasing inclusion of sweet potato meal (DSP) as a partial corn substitute. The diets were supplemented (WE) or not supplemented (NE) with exogenous enzymes, totaling six treatments (1-CSM-NE; 2- CSM-WE; 3- ISP-NE; 4- ISP-WE; 5- DSP-NE and 6- DSP-WE) with six (6) repetitions and 26 birds per experimental plot.

The SPM was included according to the growth phases established for the feeding program. Supplementation of the exogenous enzymes was done using an enzyme blend (beta-glucanase, alpha-galactosidase, amylase, betamannosidase, protease, xylanase) and monocomponent sources of phytase and lipase. The rations were formulated to be isocaloric and isoproteic.
The SPM was obtained by crushing roots and then drying the material in the sun. Two sweet potato varieties (cream and red skin, both with white pulp) were used, which were obtained in a local market and mixed in equal proportions. The material was ground with a knife mill and dried in the sun on nylon tarps for three days. When dry, the material was stored in nylon bags until just before incorporating it into the diets, when it was milled again with a $5 \mathrm{~mm}$ mesh sieve to obtain the sweet potato meal (SPM).

One sample of SPM was analyzed to determine its bromatological composition, according to the methodology proposed by Detman (2012), and a sample was sent to the ADISSEO laboratory (CEAN, Santa Maria/RS/Brazil) to determine the amino acid profile. The following values were found, which were considered in the formulation: crude matter $(\mathrm{CM})-95 \%$; mineral matter $(\mathrm{MM})-3.5 \%$; ethereal extract (EE) - 0.86\%; neutral detergent fiber (NDF) - $13.5 \%$; tyrosine $-0.07 \%$; valine $-0.15 \%$; methionine $-0.04 \%$; cystine $-<0.03 \%$; isoleucine $-0.11 \%$; aspartate $-0.29 \%$; glutamate $-0.31 \%$; serine $-0.13 \%$; glycine $-0.11 \%$; and histidine $-0.04 \%$.

The use of exogenous enzymes in the feed was implemented based on the concept of "on top of formulation" (that is, maintaining nutritional levels), with exception of phytase that had reduced levels of calcium (0.13 percentage points) and available phosphorous (0.11 percentagte points) in the diets. The diets were formulated based on the nutritional recommendations described in the Guide of Strain Cobb (2009) (Tables 1, 2, 3, 4). 
Table 1. Centesimal composition and nutritional levels calculated for the experimental feed evaluated for the pre-initial phase ( 1 to 10 days).

\begin{tabular}{|c|c|c|c|c|c|c|}
\hline Ingredients $\mathrm{g} / 100 \mathrm{~g}$ & CSM-NE & CSM-WE & ISP-NE & ISP-WE & DSP-NE & DSP-WE \\
\hline Corn & 56.40 & 57.50 & 49.98 & 51.08 & 34.58 & 35.68 \\
\hline Soybean meal & 37.64 & 37.44 & 38.34 & 38.14 & 40.03 & 39.83 \\
\hline Sweet potato meal & 0.00 & 0.00 & 5.00 & 5.00 & 17.00 & 17.00 \\
\hline Dicalcium phosphate & 1.626 & 1.088 & 1.625 & 1.088 & 1.623 & 1.085 \\
\hline Soy oil & 1.974 & 1.600 & 2.724 & 2.350 & 4.524 & 4.154 \\
\hline Limestone & 0.926 & 0.932 & 0.912 & 0.917 & 0.876 & 0.881 \\
\hline Sodium chloride & 0.504 & 0.503 & 0.487 & 0.487 & 0.447 & 0.437 \\
\hline Met-Hydroxy-Analogue ${ }^{1} 84$ & 0.353 & 0.352 & 0.362 & 0.361 & 0.384 & 0.383 \\
\hline L-Lysine $\mathrm{HCl} 78$ & 0.180 & 0.184 & 0.166 & 0.170 & 0.135 & 0.138 \\
\hline L-Threonine 98 & 0.010 & 0.010 & 0.012 & 0.012 & 0.017 & 0.017 \\
\hline Vitamin premix $^{2}$ & 0.120 & 0.120 & 0.120 & 0.120 & 0.120 & 0.120 \\
\hline Trace mineals premix ${ }^{3}$ & 0.050 & 0.050 & 0.050 & 0.050 & 0.050 & 0.050 \\
\hline Chloride-Choline $60 \%$ & 0.096 & 0.096 & 0.096 & 0.096 & 0.096 & 0.096 \\
\hline Blend Enzymes ${ }^{4}$ & 0.000 & 0.020 & 0.000 & 0.020 & 0.000 & 0.020 \\
\hline Lipase $(200,000 \mathrm{U} / \mathrm{g})$ & 0.000 & 0.005 & 0.000 & 0.005 & 0.000 & 0.005 \\
\hline Phytase $(10,000 \mathrm{U} / \mathrm{g})$ & 0.000 & 0.005 & 0.000 & 0.005 & 0.000 & 0.005 \\
\hline Narasin $10 \%$ & 0.050 & 0.050 & 0.050 & 0.050 & 0.050 & 0.050 \\
\hline Enramycin $8 \%$ & 0.012 & 0.012 & 0.012 & 0.012 & 0.012 & 0.012 \\
\hline Organic cooper $15 \%(\mathrm{Cu}(\mathrm{HMTBa}) 2)^{5}$ & 0.020 & 0.020 & 0.020 & 0.020 & 0.020 & 0.020 \\
\hline Sand (inert material) & 0.040 & 0.010 & 0.040 & 0.010 & 0.040 & 0.010 \\
\hline \multicolumn{7}{|l|}{ Calculated nutritional composition } \\
\hline Crude protein $(\%)$ & 21.80 & 21.80 & 21.80 & 21.80 & 21.80 & 21.80 \\
\hline $\operatorname{AMEn}(\mathrm{Kcal} / \mathrm{kg})^{6}$ & 2950 & 2950 & 2950 & 2950 & 2950 & 2950 \\
\hline Calcium $(\%)$ & 0.90 & 0.77 & 0.90 & 0.77 & 0.90 & 0.77 \\
\hline Avaiable Phosphorus (\%) & 0.45 & 0.34 & 0.45 & 0.34 & 0.45 & 0.34 \\
\hline Sodium $(\%)$ & 0.23 & 0.23 & 0.23 & 0.23 & 0.23 & 0.23 \\
\hline Lysine $(\%)$ & 1.32 & 1.32 & 1.32 & 1.32 & 1.32 & 1.32 \\
\hline Methionine + Cystine (\%) & 0.98 & 0.98 & 0.98 & 0.98 & 0.98 & 0.98 \\
\hline Threonine $(\%)$ & 0.86 & 0.86 & 0.86 & 0.86 & 0.86 & 0.86 \\
\hline
\end{tabular}

Threonine $(\%)$

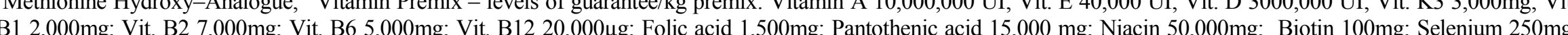
Anti-oxidant $125 \mathrm{mg} ;{ }^{3}$ Trace minerals premix - levels of guarantee/kg premix: Mn 160g; Zn 100g; Fe 100g; I 2000mg. Cu 20g. ${ }^{4} \mathrm{Enzymatic} \mathrm{activity/kg} \mathrm{diet} \mathrm{(betaglucanase}$ $250 \mathrm{U} / \mathrm{kg}$, alpha galactosidase $50 \mathrm{U} / \mathrm{kg}$, amylase $120 \mathrm{U} / \mathrm{kg}$, beta mannanase $440 \mathrm{U} / \mathrm{kg}$, protease $600 \mathrm{U} / \mathrm{kg}$, xylanase $2000 \mathrm{U} / \mathrm{kg}){ }^{5} \mathrm{Cu}$ organic $\left(\mathrm{CuHMTBa}{ }_{2}\right.$ copper linkage with two molecules of acid thio-methio butanoic which is methionine hydroxy-analogue equivalent) $30 \mathrm{mg} / \mathrm{kg}$. ${ }^{6}$ AMEn- apparent metabolizable energy corrected by nitrogen balance. 
Table 2. Centesimal composition and nutritional levels calculated for the experimental feed evaluated for the initial phase (11 to 22 days)

\begin{tabular}{|c|c|c|c|c|c|c|}
\hline Ingredients $\mathrm{g} / 100 \mathrm{~g}$ & CSM-NE & CSM-WE & ISP-NE & ISP-WE & DSP-NE & DSP-WE \\
\hline Corn & 60.45 & 61.55 & 48.89 & 49.99 & 43.76 & 44.86 \\
\hline Soybean meal & 33.06 & 32.86 & 34.33 & 34.13 & 34.89 & 34.70 \\
\hline Sweet potato meal & 0.00 & 0.00 & 9.00 & 9.00 & 13.00 & 13.00 \\
\hline Dicalcium phosphate & 1.517 & 0.887 & 1.515 & 0.860 & 1.515 & 0.848 \\
\hline Soy oil & 2.765 & 2.390 & 4.115 & 3.741 & 4.715 & 4.341 \\
\hline Limestone & 0.881 & 0.979 & 0.855 & 0.978 & 0.843 & 0.977 \\
\hline Sodium chloride & 0.482 & 0.482 & 0.452 & 0.452 & 0.439 & 0.439 \\
\hline Met-Hydroxy-Analogue ${ }^{1} 84$ & 0.300 & 0.165 & 0.316 & 0.315 & 0.324 & 0.322 \\
\hline L-Lysine $\mathrm{HCl} 78$ & 0.165 & 0.169 & 0.141 & 0.145 & 0.130 & 0.134 \\
\hline L-Threonine 98 & 0.000 & 0.000 & 0.002 & 0.002 & 0.004 & 0.004 \\
\hline Vitamin premix $^{2}$ & 0.120 & 0.120 & 0.120 & 0.120 & 0.120 & 0.120 \\
\hline Trace mineals premix ${ }^{3}$ & 0.050 & 0.050 & 0.050 & 0.050 & 0.050 & 0.050 \\
\hline Chloride-Choline $60 \%$ & 0.096 & 0.096 & 0.096 & 0.096 & 0.096 & 0.096 \\
\hline Blend Enzymes ${ }^{4}$ & 0.000 & 0.020 & 0.000 & 0.020 & 0.000 & 0.020 \\
\hline Lipase $(200,000 \mathrm{U} / \mathrm{g})$ & 0.000 & 0.005 & 0.000 & 0.005 & 0.000 & 0.005 \\
\hline Phytase $(10,000 \mathrm{U} / \mathrm{g})$ & 0.000 & 0.005 & 0.000 & 0.005 & 0.000 & 0.005 \\
\hline Narasin $10 \%$ & 0.070 & 0.070 & 0.070 & 0.070 & 0.070 & 0.070 \\
\hline Enramycin $8 \%$ & 0.012 & 0.012 & 0.012 & 0.012 & 0.012 & 0.012 \\
\hline Organic cooper $15 \%(\mathrm{Cu}(\mathrm{HMTBa}) 2)^{5}$ & 0.020 & 0.020 & 0.020 & 0.020 & 0.020 & 0.020 \\
\hline Sand (inert material) & 0.040 & 0.010 & 0.040 & 0.010 & 0.040 & 0.010 \\
\hline \multicolumn{7}{|l|}{ Calculated nutritional composition } \\
\hline Crude protein $(\%)$ & 20.00 & 20.00 & 20.00 & 20.00 & 20.00 & 20.00 \\
\hline $\operatorname{AMEn}(\mathrm{Kcal} / \mathrm{kg})^{6}$ & 3050 & 3050 & 3050 & 3050 & 3050 & 3050 \\
\hline Calcium $(\%)$ & 0.84 & 0.71 & 0.84 & 0.71 & 0.84 & 0.71 \\
\hline Avaiable Phosphorus (\%) & 0.42 & 0.31 & 0.42 & 0.31 & 0.42 & 0.31 \\
\hline Sodium $(\%)$ & 0.22 & 0.22 & 0.22 & 0.22 & 0.22 & 0.22 \\
\hline Lysine $(\%)$ & 1.19 & 1.19 & 1.19 & 1.19 & 1.19 & 1.19 \\
\hline Methionine + Cystine (\%) & 0.89 & 0.89 & 0.89 & 0.89 & 0.89 & 0.89 \\
\hline Threonine $(\%)$ & 0.78 & 0.78 & 0.78 & 0.78 & 0.78 & 0.78 \\
\hline
\end{tabular}

Threonine (\%)

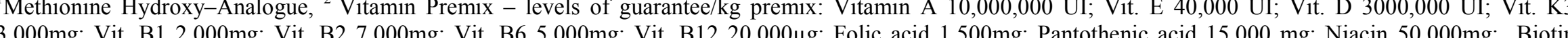
$100 \mathrm{mg}$; Selenium $250 \mathrm{mg}$, Anti-oxidant $125 \mathrm{mg}$; ${ }^{3}$ Trace minerals premix - levels of guarantee/kg premix: Mn $160 \mathrm{~g}$; Zn 100g; Fe $100 \mathrm{~g}$; I 2000mg. Cu 20g. ${ }^{4}$ Enzymatic activity $/ \mathrm{kg}$ diet (betaglucanase $250 \mathrm{U} / \mathrm{kg}$, alpha galactosidase $50 \mathrm{U} / \mathrm{kg}$, amylase $120 \mathrm{U} / \mathrm{kg}$, beta mannanase $440 \mathrm{U} / \mathrm{kg}$, protease $600 \mathrm{U} / \mathrm{kg}$, xylanase $2000 \mathrm{U} / \mathrm{kg}$ ). ${ }^{5} \mathrm{Cu}$ organic $\left(\mathrm{CuHMTBa}_{2}\right.$ copper linkage with two molecules of acid thio-methio butanoic which is methionine hydroxy-analogue equivalent) $30 \mathrm{mg} / \mathrm{kg} .{ }^{6} \mathrm{AMEn}-\mathrm{apparent}$ metabolizable energy corrected by nitrogen balance. 
Table 3. Centesimal composition and nutritional levels calculated for the experimental feed evaluated for the growth phase (23 to 33 days)

\begin{tabular}{|c|c|c|c|c|c|c|}
\hline Ingredients $\mathrm{g} / 100 \mathrm{~g}$ & CSM-NE & CSM-WE & ISP-NE & ISP-WE & DSP-NE & DSP-WE \\
\hline Corn & 63.90 & 65.00 & 47.24 & 48.30 & 52.36 & 53.46 \\
\hline Soybean meal & 28.32 & 28.12 & 30.11 & 29.92 & 29.56 & 29.36 \\
\hline Sweet potato meal & 0.00 & 0.00 & 13.00 & 13.00 & 9.00 & 9.00 \\
\hline Dicalcium phosphate & 1.363 & 0.825 & 1.361 & 0.823 & 1.361 & 0.825 \\
\hline Soy oil & 4.378 & 4.001 & 6.320 & 5.949 & 5.722 & 5.353 \\
\hline Limestone & 0.805 & 0.811 & 0.765 & 0.771 & 0.778 & 0.783 \\
\hline Sodium chloride & 0.461 & 0.461 & 0.418 & 0.418 & 0.431 & 0.431 \\
\hline Met-Hydroxy-Analogue ${ }^{1} 84$ & 0.275 & 0.274 & 0.304 & 0.303 & 0.295 & 0.294 \\
\hline L-Lysine $\mathrm{HCl} 78$ & 0.145 & 0.149 & 0.118 & 0.122 & 0.126 & 0.130 \\
\hline L-Threonine 98 & 0.002 & 0.002 & 0.010 & 0.010 & 0.007 & 0.007 \\
\hline Vitamin premix $^{2}$ & 0.100 & 0.100 & 0.100 & 0.100 & 0.100 & 0.100 \\
\hline Trace mineals premix ${ }^{3}$ & 0.050 & 0.050 & 0.050 & 0.050 & 0.050 & 0.050 \\
\hline Chloride-Choline $60 \%$ & 0.067 & 0.067 & 0.067 & 0.067 & 0.067 & 0.067 \\
\hline Blend Enzymes ${ }^{4}$ & 0.000 & 0.020 & 0.000 & 0.020 & 0.000 & 0.020 \\
\hline Lipase $(200,000 \mathrm{U} / \mathrm{g})$ & 0.000 & 0.005 & 0.000 & 0.005 & 0.000 & 0.005 \\
\hline Phytase $(10,000 \mathrm{U} / \mathrm{g})$ & 0.000 & 0.005 & 0.000 & 0.005 & 0.000 & 0.005 \\
\hline Narasin $10 \%$ & 0.070 & 0.070 & 0.070 & 0.070 & 0.070 & 0.070 \\
\hline Enramycin $8 \%$ & 0.010 & 0.010 & 0.010 & 0.010 & 0.010 & 0.010 \\
\hline Organic cooper $15 \%(\mathrm{Cu}(\mathrm{HMTBa}) 2)^{5}$ & 0.020 & 0.020 & 0.020 & 0.020 & 0.020 & 0.020 \\
\hline Sand (inert material) & 0.040 & 0.010 & 0.040 & 0.010 & 0.040 & 0.010 \\
\hline \multicolumn{7}{|l|}{ Calculated nutritional composition } \\
\hline Crude protein $(\%)$ & 18.10 & 18.10 & 18.10 & 18.10 & 18.10 & 18.10 \\
\hline $\operatorname{AMEn}(\mathrm{Kcal} / \mathrm{kg})^{6}$ & 3200 & 3200 & 3200 & 3200 & 3200 & 3200 \\
\hline Calcium $(\%)$ & 0.76 & 0.63 & 0.76 & 0.63 & 0.76 & 0.63 \\
\hline Avaiable Phosphorus (\%) & 0.38 & 0.27 & 0.38 & 0.27 & 0.38 & 0.27 \\
\hline Sodium $(\%)$ & 0.21 & 0.21 & 0.21 & 0.21 & 0.21 & 0.21 \\
\hline Lysine $(\%)$ & 1.05 & 1.05 & 1.05 & 1.05 & 1.05 & 1.05 \\
\hline Methionine + Cystine (\%) & 0.82 & 0.82 & 0.82 & 0.82 & 0.82 & 0.82 \\
\hline Threonine $(\%)$ & 0.71 & 0.71 & 0.71 & 0.71 & 0.71 & 0.71 \\
\hline
\end{tabular}

Threonine $(\%)$

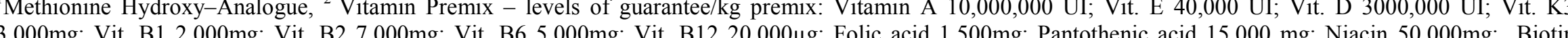
$100 \mathrm{mg}$; Selenium $250 \mathrm{mg}$, Anti-oxidant $125 \mathrm{mg}$; ${ }^{3}$ Trace minerals premix - levels of guarantee/kg premix: Mn $160 \mathrm{~g}$; Zn 100g; Fe $100 \mathrm{~g}$; I 2000mg. Cu 20g. ${ }^{4}$ Enzymatic activity $/ \mathrm{kg}$ diet (betaglucanase $250 \mathrm{U} / \mathrm{kg}$, alpha galactosidase $50 \mathrm{U} / \mathrm{kg}$, amylase $120 \mathrm{U} / \mathrm{kg}$, beta mannanase $440 \mathrm{U} / \mathrm{kg}$, protease $600 \mathrm{U} / \mathrm{kg}$, xylanase $2000 \mathrm{U} / \mathrm{kg}$ ). ${ }^{5} \mathrm{Cu}$ organic $\left(\mathrm{CuHMTBa}_{2}\right.$ copper linkage with two molecules of acid thio-methio butanoic which is methionine hydroxy-analogue equivalent) $30 \mathrm{mg} / \mathrm{kg} .{ }^{6} \mathrm{AMEn}-\mathrm{apparent}$ metabolizable energy corrected by nitrogen balance. 
Table 4. Centesimal composition and nutritional levels calculated for the experimental feed evaluated for the final phase ( 34 to 39 days)

\begin{tabular}{|c|c|c|c|c|c|c|}
\hline Ingredients $\mathrm{g} / 100 \mathrm{~g}$ & CSM-NE & CSM-WE & ISP-NE & ISP-WE & DSP-NE & DSP-WE \\
\hline Corn & 63.24 & 64.33 & 41.44 & 42.54 & 56.92 & 57.92 \\
\hline Soybean meal & 28.19 & 27.99 & 30.53 & 30.34 & 28.88 & 28.68 \\
\hline Sweet potato meal & 0.00 & 0.00 & 17.00 & 17.00 & 5.00 & 5.00 \\
\hline Dicalcium phosphate & 1.366 & 0.828 & 1.363 & 0.826 & 1.365 & 0.824 \\
\hline Soy oil & 5.229 & 4.858 & 7.769 & 7.398 & 5.976 & 5.604 \\
\hline Limestone & 0.803 & 0.808 & 0.751 & 0.755 & 0.788 & 0.792 \\
\hline Sodium chloride & 0.462 & 0.462 & 0.405 & 0.405 & 0.455 & 0.454 \\
\hline Met-Hydroxy-Analogue ${ }^{1} 84$ & 0.280 & 0.279 & 0.317 & 0.316 & 0.291 & 0.290 \\
\hline L-Lysine $\mathrm{HCl} 78$ & 0.152 & 0.156 & 0.177 & 0.120 & 0.141 & 0.144 \\
\hline L-Threonine 98 & 0.006 & 0.006 & 0.017 & 0.017 & 0.009 & 0.009 \\
\hline$V_{\text {itamin }}$ premix ${ }^{2}$ & 0.050 & 0.050 & 0.050 & 0.050 & 0.050 & 0.050 \\
\hline Trace mineals premix ${ }^{3}$ & 0.050 & 0.050 & 0.050 & 0.050 & 0.050 & 0.050 \\
\hline Chloride-Choline $60 \%$ & 0.067 & 0.067 & 0.067 & 0.067 & 0.067 & 0.067 \\
\hline Blend Enzymes ${ }^{4}$ & 0.000 & 0.020 & 0.000 & 0.020 & 0.000 & 0.020 \\
\hline Lipase $(200,000 \mathrm{U} / \mathrm{g})$ & 0.000 & 0.005 & 0.000 & 0.005 & 0.000 & 0.005 \\
\hline Phytase $(10,000 \mathrm{U} / \mathrm{g})$ & 0.000 & 0.005 & 0.000 & 0.005 & 0.000 & 0.005 \\
\hline Enramycin $8 \%$ & 0.006 & 0.006 & 0.006 & 0.006 & 0.006 & 0.006 \\
\hline Organic cooper $15 \%(\mathrm{Cu}(\mathrm{HMTBa}) 2)^{5}$ & 0.020 & 0.020 & 0.020 & 0.020 & 0.020 & 0.020 \\
\hline Sand (inert material) & 0.090 & 0.060 & 0.090 & 0.060 & 0.090 & 0.060 \\
\hline \multicolumn{7}{|l|}{ Composição Nutricional Calculada } \\
\hline Crude protein $(\%)$ & 18,00 & 18,00 & 18,00 & 18,00 & 18,00 & 18,00 \\
\hline $\operatorname{AMEn}(\mathrm{Kcal} / \mathrm{kg})^{6}$ & 3250 & 3250 & 3250 & 3250 & 3250 & 3250 \\
\hline Calcium $(\%)$ & 0,76 & 0,63 & 0,76 & 0,63 & 0,76 & 0,63 \\
\hline Avaiable Phosphorus (\%) & 0,38 & 0,27 & 0,38 & 0,27 & 0,38 & 0,27 \\
\hline Sodium $(\%)$ & 0,21 & 0,21 & 0,21 & 0,21 & 0,21 & 0,21 \\
\hline Lysine $(\%)$ & 1,05 & 1,05 & 1,05 & 1,05 & 1,05 & 1,05 \\
\hline Methionine + Cystine (\%) & 0,82 & 0,82 & 0,82 & 0,82 & 0,82 & 0,82 \\
\hline Threonine $(\%)$ & 0,71 & 0,71 & 0,71 & 0,71 & 0,71 & 0,71 \\
\hline
\end{tabular}

${ }^{1}$ Methionine Hydroxy-Analogue, ${ }^{2}$ Vitamin Premix - levels of guarantee/kg premix: Vitamin A 10,000,000 UI; Vit. E 40,000 UI; Vit. D 3000,000 UI; Vit. K3

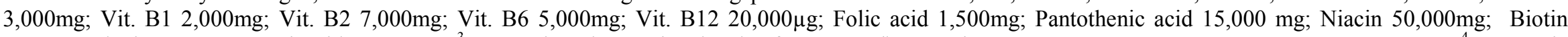
$100 \mathrm{mg}$; Selenium $250 \mathrm{mg}$, Anti-oxidant $125 \mathrm{mg}$; ${ }^{3}$ Trace minerals premix - levels of guarantee/kg premix: Mn $160 \mathrm{~g} ; \mathrm{Zn} 100 \mathrm{~g}$; Fe $100 \mathrm{~g}$; I 2000mg. Cu 20g. ${ }^{4}$ Enzymatic activity $/ \mathrm{kg}$ diet (betaglucanase 250U/kg, alpha galactosidase $50 \mathrm{U} / \mathrm{kg}$, amylase $120 \mathrm{U} / \mathrm{kg}$, beta mannanase $440 \mathrm{U} / \mathrm{kg}, \mathrm{protease} 600 \mathrm{U} / \mathrm{kg}$, xylanase $2000 \mathrm{U} / \mathrm{kg}$ ). ${ }^{5} \mathrm{Cu}$ organic $\left(\mathrm{CuHMTBa}_{2}\right.$ copper linkage with two molecules of acid thio-methio butanoic which is methionine hydroxy-analogue equivalent) $30 \mathrm{mg} / \mathrm{kg} .{ }^{6} \mathrm{AMEn}-\mathrm{apparent}$ metabolizable energy corrected by nitrogen balance. 
To evaluate the zootechnical performance, the birds were weighed where they were housed at 21 and 39 days of age. The feed and leftovers were weighted after each phase to determine consumption and calculate the feed conversion. Viability (100 - \% mortality) of the birds was determined at the end of the rearing cycle (on day 39).

On day 22, one bird per plot (of representative weight) was weighed after fasting for 3 hours, euthanized by cervical dislocation and the entire gastrointestinal track was removed and the biometry was analyzed (relative weight of the liver and pancreas). On day 40 these measurements were taken again, and the weights of the liver and pancreas were adjusted.

The intestinal morphometry was conducted in segments of 3 to $4 \mathrm{~cm}$ of the jejunum; slides were made following the methodology described by Molinaro et al. (2010). For the histometric analyses, the slides were observed and photographed using a LEICA ICC50 HD ${ }^{\circledR}$ binocular light microscope, coupled to a digital camera and a computer with the image software Leica LAS EZ® (Leica Microsystems, Buffalo Grove, USA). The photomicrographs were analyzed with the software Image $\mathbf{J}^{\circledR}$. The height and width of the villi, as well as the crypt depth, were measured at this time. To calculate surface absorption (SA), the methodology in Sakamoto et al. (2009) was employed using the following formula: SA $(\mathrm{mm} 2)=$

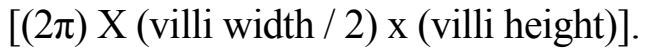

On day 40, one bird from each plot was slaughtered to determine the yield of the carcass and cuts. The bird was weight and, subsequently, the entire carcass was cleaned and eviscerated (without the head, neck and feet), placed on ice for 45 min., and the breasts, drumstick with thigh, and abdominal fat were separated. The yields of the breast and leg (drumstick + thigh) cuts, and the abdominal fat, were determined in relation to the eviscerated carcass weight (without the feet, neck and head).

The abdominal fat was composed of adipose tissue from the gizzard to the cloacal sac, according to the methodology described by Smith (1993).

For meat quality, the breast muscle (pectoralis major) was removed and measured; the $\mathrm{pH}$ was measured with a $\mathrm{pH}$ meter and coloration was evaluated 45 minutes and 24 hours postmortem using a KONIKA MINOLTA CHROMA METER - A177 (CIELAB) - (BURBUT, 1997; HONIKEL, 1998).

The pigmentation of the feet was measured on day 39 using a DMS color fan; the color of 1 bird/plot was measured. Fan values were adjusted to the CIELAB reading to obtain the yellow intensity value $\left(b^{*}\right)$ of the drumstick based on the methodology proposed by Burbut (1997).

The statistical analysis was conducted using the packet SISVAR, as described by Ferreira (2000), and used the F test and Tukey's test to detect differences. A significance level of $\alpha=0.05$ was adopted for all of the tests.

\section{RESULTS AND DISCUSSION}

There was no interaction $(p>0.05)$, nor effect of the isolated factors, on feed intake (FI) by the broiler chickens during the pre-initial and initial phases (1 to 22 days) and for the entire rearing period (1 to 39 days old). This allows us to infer that the SPM inclusion levels (partial substitution for corn) evaluated did not interfere with the acceptability of the birds. This result corroborates the results of various studies (NUNES et al. 2011; AFOLAYAN et al. 2013; PARENTE et al. 2014; BECKFORD \& BARTLETT, 2015) that also found no change in FI when using SPM. 
The diets were formulated to have the same energy profile, which might have been the reason why the FI among the different groups was the same for the diets.

An interaction $(p<0.05)$ between the factors evaluated for weight gain (WG) was found for the 1 to 21-day period (Table 5). For the supplementation/addition of the exogenous enzymes, the greatest WG was observed for the birds fed the CSM diet in relation to those fed the ISP and DSP diets, which did not differ from each other. Even with the exogenous enzyme supplement, WG did not improve for the ISP and DSP diets, which could be due to antinutritional factors (YAKUBU, 2014) of the sweet potato or resistance to sweet potato starch during digestion (SVIHUS, 2011).

Table 5. Performance, carcass yield (\%) and viability of broiler chickens fed SPM during the rearing period (1 to 39 days), including different diet types with and without an exogenous enzyme supplement

\begin{tabular}{|c|c|c|c|c|c|c|c|}
\hline Diet & Enyme & $\begin{array}{c}\mathrm{WG}^{1,2} \mathrm{~kg} \\
1 \text { to } 21 \\
\end{array}$ & $\begin{array}{c}\mathrm{FC}^{3} \\
1 \text { to } 21 \\
\end{array}$ & $\begin{array}{l}\text { WG kg } \\
1 \text { to } 39 \text {, }\end{array}$ & $\begin{array}{c}\mathrm{FC} \\
1 \text { to } 39\end{array}$ & $\begin{array}{c}\text { Yield } \\
\text { Carcass } \\
\end{array}$ & Viability \\
\hline \multirow{2}{*}{ CSM } & $\mathrm{NE}$ & $0.954^{\mathrm{B}}$ & 1.354 & 2.704 & 1.563 & 77.28 & 96.795 \\
\hline & WE & $1.015^{\mathrm{aA}}$ & 1.300 & 2.720 & 1.574 & 77.31 & 96.152 \\
\hline \multirow{2}{*}{ ISP } & $\mathrm{NE}$ & 0.965 & 1.354 & 2.675 & 1.595 & 76.75 & 95.512 \\
\hline & WE & $0.968^{\mathrm{b}}$ & 1.344 & 2.686 & 1.578 & 77.56 & 97.383 \\
\hline \multirow{2}{*}{ DSP } & $\mathrm{NE}$ & 0.955 & 1.395 & 2.742 & 1.589 & 75.94 & 98.716 \\
\hline & WE & $0.974^{\mathrm{b}}$ & 1.350 & 2.761 & 1.567 & 78.34 & 98.075 \\
\hline \multicolumn{8}{|l|}{ Main effect } \\
\hline \multirow{3}{*}{ Diet } & CSM & 0.984 & $1.327^{\mathrm{b}}$ & 2.712 & 1.568 & 77.29 & 96.473 \\
\hline & ISP & 0.966 & $1.349^{\mathrm{ab}}$ & 2.680 & 1.586 & 77.16 & 96.448 \\
\hline & DSP & 0.965 & $1.373^{\mathrm{a}}$ & 2.751 & 1.578 & 77.14 & 98.395 \\
\hline \multirow{2}{*}{ Enzyme } & $\mathrm{NE}$ & 0.958 & $1.368^{\mathrm{A}}$ & 2.707 & 1.582 & 76.66 & 97.203 \\
\hline & WE & 0.985 & $1.331^{\mathrm{B}}$ & 2.722 & 1.573 & 77.74 & 97.008 \\
\hline SEM & - & 0.0064 & 0.0069 & 0.0254 & 0.0066 & 0.4415 & 0.9078 \\
\hline CV & - & 2.28 & 1.79 & 3.24 & 1.44 & 2.43 & 3.24 \\
\hline \multicolumn{8}{|l|}{ P-value } \\
\hline Diet (D) & - & 0.0746 & 0.0003 & 0.1590 & 0.1694 & 0.9752 & 0.2361 \\
\hline Enzyme (E) & - & 0.0008 & 0.0001 & 0.6096 & 0.2171 & 0.0938 & 0.8533 \\
\hline D X E & - & 0.0093 & 0.0829 & 0.9926 & 0.1866 & 0.3027 & 0.5348 \\
\hline
\end{tabular}

$\mathrm{WG}=$ weight gain; $\mathrm{FC}=$ feed conversion; $\mathrm{CSM}=$ control program with corn-soybean meal; ISP = program with increasing sweet potato meal; DSP = program with decreasing sweet potato meal; WE = with enzyme supplement; $\mathrm{NE}=$ without enzyme supplement; $\mathrm{CV}=$ coefficient of variation; $\mathrm{SEM}=$ standard error mean; D X E = interaction between diet and enzyme supplement or no supplement. ${ }^{1}$ Averages followed by different lowercase letters $(a, b)$ in the same column differ statistically from each other by Tukey's test $(\mathrm{p}<0.05)$ (as a consequence of the effect of the type of diet as a function of enzyme supplementation). ${ }^{2}$ Averages followed by different uppercase letters (A, B) in the same column differ statistically from each other by Tukey's test $(p<0.05)$ (as a consequence of the enzyme in the type of CSM diet). ${ }^{3}$ Averages followed by different lowercase and uppercase letters (a, b; A, B) differ statistically from each other by Tukey's test (effect of diet type) and the F test (effect of exogenous enzymes), respectively. 
Similar results with lower WG were found by Nunes (2011) and Parente et al. (2014) for diets that included SPM, compared to the control (CSM), as well as exogenous enzymes; although, these studies included more SPM. However, Beckford \& Bartlett (2015) found different results in a study that used increasing substitutions of sweet potato meal in the diets of broiler chickens and verified that the highest amount of SPM resulted in the greatest weight gain.

Among the CSM diets, there was a significant difference $(p<0.05)$; the one with the enzyme substitution promoted greater weight gain.

The feed conversion (FC) for the 1 to 21 day period was influenced $(p<0.05)$ by the isolated factors. The birds fed the diets that included SPM at decreasing levels (DSP) resulted in the worst FC, those with the CSM had better FC, and the diets with exogenous enzymes had the best FC.

In an analysis that added exogenous enzymes to SPM diets of broiler chickens, Nunes et al. (2010) had a different result where there was no effect of the enzymes on performance (WG and FC).

For the complete rearing period (1 to 39 days), the diet types and addition of exogenous enzymes did not exert an effect $(p>0.05)$ on $\mathrm{WG}, \mathrm{FC}$ and carcass yield of the broiler chickens. These results demonstrate there was a compensation in the performance of the birds fed SPM. Further study is needed to better understand this outcome. However, some hypotheses are related to the type of starch in the diet, based on the stage, the presence of sucrose (simple sugar), or even the possible stimulus caused by resistant starch (Stefanello et al. 2015) in SPM that could have contributed to the development of intestinal mucosal, improving how the diets were used and resulting in a compensation and adjustment of WG and $\mathrm{FC}$ during this period.

The results for carcass yield corroborate those encountered by Beckford \& Bartlett (2015), who analyzed substituting up to $30 \%$ SPM in the diets of chickens.

No interaction $(p>0.05)$ was verified between the diet types and supplementation of exogenous enzymes for relative weight of the liver and pancreas at days 22 and 40; however, there was a significant isolated effect of the diet types $(p<0.05)$ on the relative weight of the pancreas (Table 6).

Including sweet potato resulted in a greater relative weight of the pancreas in comparison to the CSM program. At both 22 and 40 days old, the weight of the pancreas varied significantly $(p<0.05)$ in response to the levels of sweet potato meal used for each development phase. An increase in the relative weight of the pancreas was also found by Nunes et al. (2010) in a study that used sweet potato meal in chicken diets.

Hypotheses that might explain this result (increase in weight of the pancreas when using SPM) are related to an increase in soybean meal and lipids in the formulation of the feed that included SPM (ISP and DSP), which is needed to correct protein and energy levels that are known to be lower in SPM compared to corn. Thus, proportionally, the diets with SPM contained more non starch polysaccharides (NSPs) and lipids, which could have caused the pancreas to secrete more enzymes, leading to an increase in the relative weight of the organ (hypertrophy).

On the other hand, according to Bedford (1996), the content of resistant starch, which includes NSPs and/or trypsin inhibitors (mostly in the SPM diets), are difficult to digest during the first weeks of rearing if they are in quantities above the conventional amount, and this has 
an effect on the organs associated with the digestive tract.

There was no interaction $(p>0.05)$ for the average absorption surface of the villi of the jejunum on day 22 . However, when only the diet factor was evaluated the response was significant $(\mathrm{p}<0.05)$ for this variable, where the surface was larger for the DSP diet compared to the CSM diet (Table 6). Supplementing the feed with exogenous enzymes did not exert an effect $(p>0.05)$ on the absorption surface of the jejunum villi on day 22 of rearing.

Table 6. Relative weight (\%) of the liver and pancreas and absorption surface of the jejunum (SA) of broiler chickens fed sweet potato meal, for days 22 and 40, in different diets with and without an exogenous enzyme supplement

\begin{tabular}{|c|c|c|c|c|c|c|}
\hline Diet & Enzyme & $\begin{array}{c}\text { Liver } \\
22 \text { days }\end{array}$ & $\begin{array}{c}\text { Liver } \\
40 \text { days }\end{array}$ & $\begin{array}{c}\text { Pancreas } \\
22 \text { days }\end{array}$ & $\begin{array}{c}\text { Pancreas }^{1} \\
40 \text { days }\end{array}$ & $\begin{array}{l}\text { SA } 22 \text { days } \\
\quad\left(\mathrm{mm}^{2}\right)\end{array}$ \\
\hline \multirow{2}{*}{ CSM } & $\mathrm{NE}$ & 2.85 & 1.91 & 0.27 & 0.147 & 0.827 \\
\hline & WE & 2.75 & 2.02 & 0.28 & 0.160 & 1.032 \\
\hline \multirow{2}{*}{ ISP } & $\mathrm{NE}$ & 2.52 & 1.92 & 0.34 & 0.208 & 1.005 \\
\hline & WE & 2.68 & 1.87 & 0.38 & 0.200 & 1.220 \\
\hline \multirow{2}{*}{ DSP } & $\mathrm{NE}$ & 2.83 & 1.96 & 0.40 & 0.193 & 1.283 \\
\hline & WE & 2.83 & 1.86 & 0.35 & 0.158 & 1.112 \\
\hline \multicolumn{7}{|l|}{ Main effects } \\
\hline \multirow{3}{*}{ Diet } & CSM & 2.80 & 1.97 & $0.28^{\mathrm{b}}$ & $0.153^{b}$ & $0.929^{b}$ \\
\hline & ISP & 2.60 & 1.90 & $0.36^{\mathrm{a}}$ & $0.204^{\mathrm{a}}$ & $1.112^{\mathrm{ab}}$ \\
\hline & DSP & 2.83 & 1.91 & $0.38^{\mathrm{a}}$ & $0.176^{\mathrm{b}}$ & $1.198^{\mathrm{a}}$ \\
\hline \multirow{2}{*}{ Enzyme } & NE & 2.73 & 1.93 & 0.34 & 0.183 & 1.038 \\
\hline & WE & 2.75 & 1.92 & 0.34 & 0.173 & 1.121 \\
\hline SEM & & 0.0836 & 0.0612 & 0.0146 & 0.0067 & 0.069 \\
\hline $\mathrm{CV}$ & & 10.56 & 11.03 & 15.00 & 13.08 & 22.19 \\
\hline \multicolumn{7}{|l|}{ P-value } \\
\hline Diet (D) & & 0.1180 & 0.6989 & 0.0001 & 0.0000 & 0.0306 \\
\hline Enzyme (E) & & 0.8018 & 0.8579 & 0.9739 & 0.2070 & 0.3056 \\
\hline D X E & & 0.5564 & 0.4600 & 0.1703 & 0.0528 & 0.0962 \\
\hline
\end{tabular}

$\mathrm{CSM}=$ control program with corn-soybean meal; ISP = program with increasing sweet potato meal; DSP = program with decreasing sweet potato meal; $\mathrm{WE}=$ with enzyme supplement; $\mathrm{NE}=$ without enzyme supplement; $\mathrm{CV}=$ coefficient of variation; SEM = standard error mean; D X E = interaction between diet and enzyme supplement or no supplement. ${ }^{1}$ Averages followed by different lowercase letters $(a, b)$ in the same column differ statistically from each other by Tukey's test $(p<0.05)$.

The isolated effect of the diet types suggests that the ISP and DSP diets stimulated the development of the absorption surface of the intestine compared to the control (CSM). These results could be associated with the organism compensating (anatomically and physiologically) to increase digestion and absorption of nutrients due to the limitations of the ISP and DSP diets, which is possibly linked to the starch in the SPM. Further, sources of starch resistant or linked to NSPs may have promoted an increase in viscosity that stimulated villi growth and, consequently, an increase in surface absorption, as reported by some authors (APAJALAHTI \& VIENOLA 2016; GOULART, 2016). The presence of more insoluble NSPs in SPM also impacts the intestinal morphometry, as noted by Hetland et al. (2004) and Pandi et al. (2016), which may 
help explain the response observed in this study.

These results corroborate those of Iji et al. (2001), who tested broiler chicken diets with diverse levels of viscosity to promote intestinal development and to use as bird feed. Until a certain viscosity level, there was a direct and positive relation, as well as an increase in the density and height of the villi, which resulted in a positive response for weight gain.

For the chickens evaluated on day 40, there was no interaction of significant difference $(\mathrm{p}<0.05)$ between the factors evaluated for feet pigmentation, meat quality ( $\mathrm{pH}$ and $\mathrm{L}^{*}$ ), carcass yield (breasts and legs), and relative weight of abdominal fat (Table 7). Both the inclusion of sweet potato meal and the use of exogenous enzymes had no influence on these variables. On average, the postmortem $\mathrm{pH}$ ranged from 5.5 to 6.2 and $\mathrm{L}^{*}$ ranged from 44 to 53 , which are normal values for chicken of good quality (BURBUT, 1997).

Table 7. Meat quality parameters and breast, drumstick + thigh and abdominal fat yield $(\mathrm{g} / 100 \mathrm{~g})$ on day 40 , and feet pigmentation $\left(\mathrm{FP}-\mathrm{b}^{*}\right)$ on day 39 , of chickens fed sweet potato meal in three diets with and without an exogenous enzyme supplement

\begin{tabular}{|c|c|c|c|c|c|c|c|}
\hline Diets & Enzyme & FP & $\mathrm{L}^{*}(\mathrm{PM})$ & $\mathrm{pH}(\mathrm{PM})$ & $\begin{array}{c}\text { Abdominal } \\
\text { fat }\end{array}$ & Breast & $\begin{array}{c}\text { drumstick } \\
+ \\
\text { thigh } \\
\end{array}$ \\
\hline \multirow{2}{*}{ CSM } & $\mathrm{NE}$ & 42.88 & 50.57 & 6.00 & 1.45 & 35.72 & 27.60 \\
\hline & WE & 43.54 & 51.34 & 6.14 & 1.62 & 35.29 & 27.85 \\
\hline \multirow{2}{*}{ ISP } & $\mathrm{NE}$ & 43.96 & 51.65 & 5.91 & 1.76 & 34.59 & 26.06 \\
\hline & WE & 43.68 & 51.76 & 6.14 & 1.60 & 36.22 & 27.21 \\
\hline \multirow{2}{*}{ DSP } & $\mathrm{NE}$ & 46.73 & 51.68 & 6.09 & 1.87 & 35.62 & 29.34 \\
\hline & WE & 42.55 & 51.79 & 6.00 & 1.75 & 35.67 & 27.76 \\
\hline \multicolumn{8}{|l|}{ Main effects } \\
\hline \multirow{3}{*}{ Diets } & CSM & 43.21 & 50.95 & 6.07 & 1.53 & 35.50 & 27.72 \\
\hline & ISP & 43.82 & 51.70 & 6.03 & 1.68 & 35.40 & 26.64 \\
\hline & DSP & 44.64 & 51.74 & 6.07 & 1.81 & 35.64 & 28.55 \\
\hline \multirow{2}{*}{ Enzyme } & $\mathrm{NE}$ & 44.52 & 51.63 & 6.10 & 1.69 & 35.31 & 27.66 \\
\hline & WE & 43.26 & 51.30 & 6.00 & 1.65 & 35.73 & 27.61 \\
\hline SEM & - & 0.0067 & 0.7210 & 0.0401 & 0.1225 & 0.7151 & 0.5765 \\
\hline $\mathrm{CV}$ & - & 9.27 & 4.85 & 2.58 & 25.33 & 6.98 & 7.23 \\
\hline \multicolumn{8}{|l|}{ P-value } \\
\hline Diets(D) & - & 0.6919 & 0.6897 & 0.7660 & 0.2877 & 0.9724 & 0.0789 \\
\hline Enzyme (E) & - & 0.3575 & 0.6956 & 0.0792 & 0.7912 & 0.6171 & 0.9321 \\
\hline D X E & - & 0.3158 & 0.9329 & 0.0525 & 0.5894 & 0.5738 & 0.2496 \\
\hline
\end{tabular}

$\mathrm{FP}=$ feet pigmentation; $\mathrm{PM}=$ postmortem; $\mathrm{L}^{*}=$ luminosity; $\mathrm{b}^{*}=$ intensity of yellow; $\mathrm{CSM}=$ control program with corn-soybean meal; ISP = program with increasing sweet potato meal; DSP = program with decreasing sweet potato meal; $\mathrm{WE}=$ with enzyme supplement; $\mathrm{NE}=$ without enzyme supplement; $\mathrm{CV}=$ coefficient of variation; SEM = standard erro mean; $\mathrm{D} X \mathrm{X}=-$ interaction between diet and enzyme supplement or no supplement. ${ }^{1}$ Averages followed by different lowercase letters $(\mathrm{a}, \mathrm{b})$ in the same column differ statistically from each other by Tukey's test $(p<0.05)$ (as a consequence of an exogenous enzyme supplement in the diets). 
The $\mathrm{pH}$ and $\mathrm{L}^{*}$ (luminosity) values recorded in this study indicate that the meat quality encountered is within the normal patterns observed, since rigor mortis of the birds took 15 to 45 minutes (BURBUT, 1997; BRESSAN \& BERAQUET, 2004; SOUZA et al. 2010). This leads us to conclude that adding SPM to the diets did not affect the meat quality of the broiler chickens.

In this study, the abdominal fat was not influenced by the addition of SPM and supplementation of enzymes in the diets. This differs from Beckford \& Bartlett, (2015), who found that for the maximum amount of SPM added there was more abdominal fat (numerically) compared to the control, although there was no statistical difference.

Including an increasing (ISP) and decreasing (DSP) amount of sweet potato meal, independent of the broilers' age and inclusion quantity used, appears to have had an effect on the pancreas and villi, which is attributed to the bromatological nature of sweet potato.

Independent of the program, sweet potato can be used to partially substitute corn.

Sweet potato meal can be used in broiler chicken feed without harming the intestinal integrity and internal organs linked to the digestive system, guaranteeing good performance, carcass yield, parts yield, and meat quality.

\section{REFERENCES}

AFOLAYAN, S.B.; DAFWANG, I.I.; SEKONI, A.; JEGEDE, J.O. Effect of Dietary Maize Substitution with sweet potatoes meal on performance of growers (10-22 weeks) and subsequent egg production (23-35 weeks). Asian journal of poultry science, $v .7, n .2$, p.55-64, 2013.
BECKFORD, R.C. E.; BARTLETT, J.R. Inclusion levels of sweet potato root meal in the diet of broilers I. effect on performance, organ weights, and carcass quality. Poutry Science, v.94, p. 1316-1322, 2015.

BEDFORD, M.R. Interaction Between Ingested Feed and the Digestive System in Poultry. Journal of Appllied

Poultry Research, v.5, p.86-95, 1996.

BURBUT, B. Problem of pale soft e exudative meat in broiler chickens.

Journal of British Poultry Science, v.38, p.355-358, 1997.

COBB-Vantress. Manual de manejo de frangos de corte. 2009. Disponível em: $<$ https://wp.ufpel.edu.br/avicultura/files/2 012/04/Cobb-Manual-Frango-CorteBR.pdf.>. Acesso em: 17 nov. 2016.

DETMAN, E.; SOUZA, M.A.; VALADARES FILHO, S.C. Métodos para análise de alimentos. Visconde do Rio Branco: Universidade Federal de Viçosa, 2012. 214p.

FERREIRA, D.F. SISVAR - Sistema de análises de variância para dados balanceados. Lavras: DEX/UFLA, 2000 .

GOULART, F.R.; ADORIAN, T.J.; MOMBACH, P.I.; SILVA, L.P. Importance of dietary fi ber in nonruminant animal nutrition. Revista de Ciências e Inovação do IF Farroupilla, v.1, p.1-11, 2016.

HONIKEL, K.O. Reference methods for the assessment of physical characteristics of meat. Meat Science, v.49, p.447-457, 1998. 
HORVATOVIC, M.P.; GLAMOCIC, D.; ZIKIC, D. ; HADNADJEV, T.D.

Performance and some intestinal functions of broilers fed diets with different inclusion levels of sunflower meal and supplemented or not with enzymes. Brazilian Journal of Poultry Science, v.17, n.1, p.25-30, 2015.

IJI, P.A.; SAKI, A.A.; TIVEY, D.R. Intestinal development and body growth of broiler chicks on diets supplemented with non-starch polysaccharides.

Animal Feed Science and Technology, v.89, p.175-188, 2001.

LAURIE, S.; FABER, M.; ADEBOLA, P. BELETE, A. Biofortification of sweet potatoes for food and nutricion security in South africa. Food Research International Jornal, v.76, p.962-970, 2015.

MOLINARO, E.M.; CAPUTO, G.L.F. E AMENDOEIRA, M.R.R. Conceitos e métodos para a formação de profissionais em laboratório de saúde. Rio de Janeiro: EPSJV / IOC, 2010. Vol 2, 290p.

NUNES, J.K.; GONÇALVES, F.M.; DALLMANN, H.M.; GENTILINI, F.P; ANCIUTI, M.A.; RUTZ, F.; MAIER, J.C.; SILVA, J.G.C. Development of the digestive tract of broilers fed diets containing sweet potato meal. Archivos de Zootecnia, v.60, n.232, p. 1105 1114, 2011.

NUNES, J.K.; ZABATELA, J.P.L.; ANCIUTI, M.A. Batata doce na dieta de frangos de corte. In: SIMPÓSIO ESTADUAL DE AGROENERGIA, 3., Pelotas, RS. Anais... Pelotas, RS: Universidade federal de pelotas, 2010.
OLIVEIRA, C.D.; SOUZA, A.F. DUDA, P.R.O.; SOUZA, A.A.D.F. Produtividade de cultivares de batatadoce, plantadas com ramas de safra anterior, conservadas durante o inverno em diferentes ambientes. Revista Técnico Científica do IFSC, v.5, p.234-241, 2014.

OLIVEIRA, A.M.S.; BLANK, A.F.; ALVES, R.P.; PINTO,V.S.; ARRIGONI-BLANK, M.F.; MALUF, W.R. Productive characteristics of sweet potato clones in three cultivation periods in São Cristóvão, Sergipe State, Brazil. Horticultura brasileira, v.33, n.3, p.377-382, 2015.

PANDI, J.; GLATZ, P.; FORDER, R.; AYALEW, W.; WARAMBOI, J.; CHOUSALKAR, K. The use of sweet potato (Ipomoea batatas (L.) Lam) root as feed ingredient for broiler finisher rations in Papua New Guinea. Animal Feed Science and Technology, v.214, p.1-11, 2016.

PARENTE, I.P.; RODRIGUES, K.F.; VAZ, R.G.M.V.; SOUSA, J.P.L.; SANTOS NETA, E.R.; ALBINO, L.F.T.; SIQUEIRA, J.C.; PAIVA, J.A. Nutritional characteristics and use the residue of sweet potato in slow growth broiler diets. Revista Brasileira de Saúde e Produção Animal [online], v.15, n.2, p.470-483, 2014.

RAVINDRAN, V. Feed enzymes: the Science, practice, and metabolic realities. Journal of Applied Poultry Reseach, v.22, p.628-636, 2013.

ROSTAGNO, H.S.; ALBINO, L.F.T.; DONZELE, J.L.; GOMES, P.C.; OLIVEIRA, R.F.; LOPES, D.C.; FERREIRA, A. S.;BARRETO, S.L.T. Tabelas brasileiras para aves $\mathrm{e}$ suínos. 3.ed. Viçosa, MG: UFV, 2011. 186p. 
SAKAMOTO, M.I. Desempenho, desenvolvimento e atividade enzimática da mucosa intestinal de frangos de corte alimentados com dietas suplementadas com glutamina e nucleotídeos. 2009. 95f. Tese (Doutorado em Zootecnia) Universidade de São Paulo, São Paulo, São Paulo.

SET'LE, M.A.; ADEDIWURA, A.T.; OLAYIWOLA, O.E. Growth Performance of Broiler Chickens Fed Diets Containing Partially Cooked Sweet Potato Meal. Journal of Natural Sciences, v.2, p.2224-3186, 2012.

SMITH, M.O. Parts yield of broilers reared under cycling high temperatures. Poultry Science, v.72, p.1146-1150, 1993.

SOUZA, L.M.G.; MURAKAMI, A.E.; FERNANDES, J.I.M; GUERRA, R.L.H.; MARTINS, E.N. Influência do cromo no desempenho, na qualidade de carne e teor de lipídeos no plasma sanguíneo de frangos de corte. Revista Brasileira de Zootecnia, v.39, p.808814, 2010.

STEFANELLO, C.; VIEIRA, S.L.; SANTIAGO, G.O.; KINDLEIN, L.; SORBARA, J.O.B.; COWIESON, A.J. Starch digestibility, energy utilization, and growth performance of broilers fed corn-soybean basal diets supplemented with enzymes. Poultry Science Association, v.10, p.2472-2479, 2015.

SVIHUS, B. Limitations to wheat starch digestion in growing broiler chickens: a brief review. Animal Production Science, v.51, n.7, p.583-589, 2011.
WALUYO, B.; ROOSDA, A.A.; ISTIFADAH, N.; RUSWANDI, D.; KARUNIAWAN, A. Identification of fifty sweetpotato (ipomeia batata (L.) Lam.) promising clones for bioethanol raw materials. Energy procedia, v.65, p.22-28, 2015.

WARAMBOI, J.G.; DENNIEN, S.; GIDLEY, M.J.; SOPADE, P.A. Characterisation of sweetpotato from Papua New guine and australian cultivars pasting and gelatinisation properties. Food chemistry, v.126, p.1759-1770, 2011.

YAKUBU, I.J. Optimum level of utilization of cooked sweet potatoes meal (ipomeia batatas LAM) in broiler chicken diets. 2014. 45p. MSc (Thesis) - Department of Animal Science, Faculty of Agriculture, Ahmadu Bello University, Zaria, Nigeria.

Receipt date: 17/09/2017 Approval date: 18/01/2018 